\title{
Direct chemical inhibition responsible for displacement of a native herbivore by an invasive congener
}

Danielle K. Drumheller ( $\nabla$ ddrumheller2018@fau.edu )

Florida Atlantic University Charles E Schmidt College of Science https://orcid.org/0000-0001-83681072

\section{Mark I. Cook}

South Florida Water Management District

Nathan J. Dorn

Florida Atlantic University

\section{Research Article}

Keywords: chemical cues, Pomacea, invasion, displacement, growth

Posted Date: February 19th, 2021

DOl: https://doi.org/10.21203/rs.3.rs-186320/v1

License: (c) (i) This work is licensed under a Creative Commons Attribution 4.0 International License. Read Full License 


\title{
Direct chemical inhibition responsible for displacement of a native herbivore by an invasive congener
}

\author{
Danielle K. Drumheller ${ }^{*}$, Mark I. Cook ${ }^{2}$, and Nathan J. Dorn ${ }^{1}$ \\ ${ }^{1}$ Department of Biological Sciences, Florida Atlantic University, 3200 College Avenue, Davie, \\ Florida 33314, USA \\ ${ }^{2}$ South Florida Water Management District, 3301 Gun Club Road, West Palm Beach, Florida \\ 33406, USA \\ * Corresponding author: ddrumheller2018@fau.edu
}

\begin{abstract}
The mechanisms causing native displacement by invasive species are challenging to identify. We used survey data to demonstrate a local extinction of a native gastropod (Pomacea paludosa) from a Florida wetland coincident with invasion of a non-native gastropod ( $P$. maculata). We then examined the potential for $P$. maculata to displace $P$. paludosa. We used two field experiments to examine effects of densities and heterospecific interactions on juvenile growth in situ and we used lab and mesocosm experiments to explore chemically-mediated interactions between the species. Field experiments produced variable results; evidence for reduced $P$. paludosa growth in the presence of $P$. maculata was found under higher nutrient conditions with fast snail growth rates, but growth inhibition disappeared under oligotrophic conditions.

Resource reduction could not be demonstrated in the field. Juvenile P. paludosa did not avoid mucus of $P$. maculata and did not reduce feeding in response to cues. Nevertheless, exposure to mucus and waterborne cues of $P$. maculata reduced $P$. paludosa growth by $53 \%$ relative to conspecific cue exposure. In mesocosms juvenile $P$. paludosa growth was significantly negatively correlated with adult $P$. maculata waterborne cues and was particularly affected at exposures $\geq 60 \%\left(\sim 0.6 \cdot \mathrm{m}^{-2}\right)$. Combined mucus and waterborne cues appeared to further reduce growth at low exposure (20\%). We documented the first apparent local extinction of $P$. paludosa by $P$. maculata. We found no evidence for competition, but the results collectively pointed to direct chemical inhibition of growth that could be important at field scales, even at low densities.
\end{abstract}

Keywords chemical cues, Pomacea, invasion, displacement, growth

\section{Declarations}

Funding: This work was supported by the South Florida Water Management District.

Conflicts of interest/Competing interests: The authors have no competing interests.

Availability of data and material: The data that support the findings of this study are available on request from the corresponding author, DKD.

Code availability: No custom code was used in this study. Code is available on request from the corresponding author, DKD. 
Authors' contributions: DKD, NJD and MIC conceived of the studies. DKD carried out the experiments and analyzed the data with guidance from NJD. DKD and NJD wrote the manuscript with editorial feedback from MIC.

Acknowledgments: We especially thank E. Cline for his management of the study of wetlands and J. Sommer for his tireless help collecting data in the field and setting up experiments. T. Cocoves, A. LaGala, and B. McKenna also provided help with the experiments in the field. All $P$. maculata were destroyed or remained captive at FAU upon termination of this study. The work was supported by a contract from the South Florida Water Management District (to NJD at Florida Atlantic University). 


\section{Introduction}

Invasions are considered one of the greatest causes of biodiversity loss (Bellard et al. 2016), but the mechanisms of species interactions leading to local exclusions are often hard to decipher (Gurevitch and Padilla 2004, Didham et al. 2005). Invasive species interact with local communities and native species in many ways, including hybridization, predation, and competitive displacement, all of which can lead to extinction of native species (Mooney and Cleland 2001). Predation may be responsible for most biodiversity loss to invasives (Doherty et al. 2016), but both interference and exploitative competition with invaders have also resulted in the decline or displacement of native species (Kiesecker et al. 2001, Reitz and Trumble 2002). Displacement of native species by putative competitors is expected to take longer than displacement by predation and may require combinations of long-term observations and experiments to determine the potential for native displacement (Davis 2003). Chemical inhibition (i.e., allelopathy) is another potential pathway of interaction between non-native invaders and the communities they invade. While chemical inhibition causing displacement of native species is well studied among plants (Hierro and Callaway 2003) and is noted among corals (Maida et al. 1995), such a mechanism has been rarely suggested for animal interactions.

Chemically-mediated interactions are important in shaping communities and ecosystem processes (Burks and Lodge 2002). Chemical cues of competitors have been shown to reduce growth and alter morphology among animals (Relyea 2002). More commonly, chemical cues have been invoked in behavioral or other phenotypic responses of animal prey to predator risk and such studies are particularly common in freshwater ecosystems (Brönmark and Petterson 1994). Among freshwater organisms, perhaps no group has been so well studied as freshwater snails and their chemical responses to predators that induce plastic phenotypic responses and 
variable growth trajectories (Rundle and Brönmark 2001, Crowl and Covich 1990, Turner et al. 1999).

Most studies demonstrating chemical interactions among gastropods have been in the context of mate searching, avoiding predation, and foraging (Croll 1983, Brönmark and Hansson 2000). Chemically-mediated interactions might produce a form of interference competition and can be inferred if exposure to chemical cues reduced feeding or activity or habitat use (i.e., heterospecific avoidance, Raw et al. 2013), but chemical cues might also directly inhibit growth without any avoidance or behavioral change. Interspecific chemical competition or direct inhibition among gastropods could be important, although it has only been studied in a few cases. A concentrated substance from Fossaria cubensis cultures inhibited reproduction of Biomphalaria glabrata, but the mechanism was unexplored (Levy et al. 1973). In another study the growth of Physa acuta improved in water conditioned by heterospecifics, but the mechanism for enhanced growth was unexplained (Kawata and Ishigami 1992). Finally, exposure to cues of the invasive snail Tarebia granifera caused avoidance of several native snails (Assiminea $\mathrm{cf}$. capensis, Melanoides tuberculata, and Coriandria durbanensis) suggesting the potential for chemically-mediated interspecific competition through chemical cues (Raw et al. 2013).

The Florida apple snail, Pomacea paludosa, is a relatively large Ampullarid snail (30-45 mm adult shell length; Hanning 1979) native to wetlands throughout Florida including the Everglades of southern Florida. The Florida Everglades is an oligotrophic, topographically flat wetland with vegetated habitats structured by hydropatterns. The hydrologic dynamics of the Everglades is partly governed by a rainfall pattern characterized by a wet and dry season, with $80 \%$ of the rainfall delivered between June and November causing annual water elevations to fluctuate by $60 \mathrm{~cm}$ or more (Gaiser et al. 2012). A small gradient of increasing elevation and 
decreasing annual mean water depth characterizes deep slough, wet prairie, and ridge habitat. Apple snails are prey to many Everglades animals (Fogarty and Albury 1967, Snyder and Snyder 1971, Dorn and Hafsadi 2016) and provide a direct trophic link to the federally endangered snail kite, Rostrhamus sociabilis, which feeds almost exclusively on adult-sized apple snails (Snyder and Snyder 1969, Sykes et al. 1995, Cattau et al. 2010). Apple snail densities have been shown to be a determinant of snail kite demographic rates, but $P$. paludosa densities in wetlands are typically well below $1 \mathrm{~m}^{-2}$ (Cattau et al. 2014). The recent invasion of southern Florida wetlands and canals by an even larger-bodied, more fecund, and longer living South American apple snail, P. maculata, has raised concerns about competition with P. paludosa (Rawlings et al. 2007, Posch et al. 2013) although there has been no clear demonstration of displacement in the field. Lab experiments have demonstrated that $P$. paludosa growth and survival can be reduced by $P$. maculata presence (Conner et al. 2008, Posch et al. 2013). The lab studies suggested a potential role for chemical-mediated interactions between the species, but were inconclusive about the inhibitory mechanism.

In this paper we used field survey data to document an invasion by $P$. maculata and a local exclusion of P. paludosa in Florida wetlands. Using field, lab and mesocosm studies we tested for various mechanisms (e.g., resource competition, chemical interference) of interaction whereby invasive snails might inhibit population success of native apple snails. Based on our observations in the field and previous experiments (Posch et al. 2013) we predicted that juvenile native apple snails would suffer in competitive interactions with juvenile $P$. maculata in the wetlands and tested for such effects in field experiments. We followed the field experiments with additional experiments testing for direct chemical inhibition and chemically-mediated interference. 


\section{Methods}

Study area

Our surveys, field experiments and apple snail egg mass collections were conducted at the Loxahatchee Impoundment Landscape Assessment (hereafter LILA) in Palm Beach County, Florida, USA $\left(26^{\circ} 29^{\prime} 20^{\prime \prime} \mathrm{N}, 80^{\circ} 13^{\prime} 08^{\prime \prime} \mathrm{W}\right)$, which is comprised of four replicated 8 ha wetland macrocosms (referred to as M1, M2, M3, or M4). Vegetation and habitat elevation in each wetland were similar to each other and to those in the Everglades ridge and slough landscape; densely vegetated grassy ridges with adjacent lower elevation open-water sloughs and two small tree islands. Common macrophytes included Cladium jamaicense, Eleocharis spp., Sagittaria lancifolia, Pontederia cordata, Panicum spp., and Nymphea odorata. Field experiments and sampling generally took place in the sloughs, while the surveys of egg masses occurred at the ridge-slough interface (Appendix A). Water levels are mostly controlled by gates and pumps, but the hydropattern mimics the wet season (summer) and dry season (winter-spring) of the Everglades. The deepest sloughs never dry out and the shallower ridge habitats dry to sediment surfaces for approximately 3-4 months each year (February - May). Peak water depths in the late summer and fall reach $60-100 \mathrm{~cm}$ in the sloughs.

Apple snail Assemblages

We documented the invasion of $P$. maculata and assemblage shifts in apple snails in the LILA wetlands with trapping results and observations of egg masses. Throw trap sampling was used to quantify apple snail densities in LILA macrocosms for seven years between 2009 and 2020. From 2009-2012 and again from 2018-2020 aquatic fauna, including apple snails, were quantified in each LILA macrocosm using 14-15 randomly placed 1- $\mathrm{m}^{2}$ throw traps in the sloughs in the spring (February or March) and again in summer (typically late July). Animals were cleared from traps 
with a series of seine and dip net sweeps (methods in Dorn et al. 2005, Dorn and Cook 2015). Only two of the four macrocosms (M3 and M4) were sampled in the first season (2009) and thereafter all four wetland macrocosms were sampled. Comprehensive throw trapping samples across the sloughs was not conducted from 2013 to 2017 . We used the throw trap sampling to document the invasion of the LILA wetlands at a coarse scale by combining all captures across all wetlands through time.

Apple snails have low densities, typically $<0.5 \mathrm{~m}^{-2}$, so to better monitor the assemblages we quantified apple snail relative abundances at the scale of each wetland for three years during the invasion by counting egg masses laid above the water surfaces on emergent vegetation (Turner 1996). Pomacea paludosa lay pale pink to white masses of typically 15-35 eggs (Hanning 1979 , O’Hare 2010, Dorn - unpublished data) while P. maculata lay vibrant pink egg masses of small eggs that can often number up to 2000 per mass (Barnes et al. 2008). In LILA the typical egg masses appear to be smaller ( 200-900 eggs $\cdot$ mass $^{-1}$, Dorn, unpublished estimates using regressions in Kyle et al. 2014). Egg mass presence indicates adult apple snail presence and repeated surveys allowed us to identify presence and then compare relative abundances of breeding females in the LILA wetlands integrated over a breeding period (Marzolf et al. 2018). Pomacea maculata tends to reproduce at high levels in spring and summer, whereas $P$. paludosa peak egg counts tend to come in the spring before the low water point in May (Drumheller 2020).

We surveyed along the ridge habitat margins of the deep slough in all four macrocosms. The ridge-slough ecotone/interface is a habitat known to have relatively high densities of snail egg masses (Wight et al. 2017). The survey areas $\left(2634 \mathrm{~m}^{2} \pm 29.3\right.$, average \pm SD) included $2 \mathrm{~m}$ on both sides of the elevational switch between the deep slough and the ridges. The surveys included transects on the north and south side of each deep slough and densities were calculated using both 
transect areas for each macrocosm on each date. A single survey of each wetland was conducted in September 2014, but in 2019 and 2020 we conducted repeated surveys every three weeks from March until July in $2019(n=7)$ and from February until August in $2020(n=9)$. In the latter two years we conducted more temporally comprehensive surveys to make certain that egg masses of P. paludosa were not being missed and we also included receding (spring-dry season) and ascending (summer-wet season) water levels. Reproductive females lay $\leq 1$ egg mass per week and egg masses typically hatch within 16-22 days (Hanning 1979) therefore we counted only intact/unhatched egg masses and surveys were spaced every three weeks to avoid recounting egg masses. Transects were either walked or kayaked, depending on water levels. Egg mass densities were low $(<550 / \mathrm{ha})$, but all survey transects contained excess stems of preferred vegetation for oviposition, including Eleocharis cellulosa, Eleocharis interstincta, Pontederia cordata, Sagittaria lancifolia and Cladium jamaicense (Turner 1996, Smith et al. 2015).

\section{Testing for Competition in the Field}

To test for competitive impacts of juvenile $P$. maculata on juvenile $P$. paludosa growth we conducted replicated experiments in $1-\mathrm{m}^{2}$ cages in the sloughs of one wetland (M2) in the summers of 2019 and 2020. In both experiments we measured P. paludosa growth with or without $P$. maculata using a replacement design. Experimental cages had a 1-mm mesh, a closed bottom, and an open top. Cages were placed in the sloughs two weeks before snails were stocked each year to allow algae to accumulate on surfaces. Because periphyton (i.e., partly attached and partly floating metaphytic algae) is an important food resource for hatchling apple snails (Shuford et al. 2005) we added $1000 \mathrm{~mL}$ of periphyton and associated submerged aquatic vegetation (mostly Chara sp.) to each cage to standardize food availability. Before adding the periphyton it was examined and any apple snail predators (i.e., crayfish or hemipterans) or other snails were removed. Remaining 
periphyton volume $(\mathrm{mL})$ in cages was measured at the end of each experiment. Artificial rope vegetation (4 polypropylene strands, each $30 \mathrm{~cm}$ long) was added to each cage to serve as a standardized substrate for colonizing periphyton. Water levels were rising during this season and average depths in cages varied through time from $27-38 \mathrm{~cm}$ in 2019 and $23-45 \mathrm{~cm}$ in 2020 . We measured snail growth (final P. paludosa biomass) over five weeks starting in June of each year; survival was high $\left(96 \% \pm 0.02 \% \cdot\right.$ cage $^{-1}$, average \pm SE) and did not differ between treatments in either year.

Apple snail egg masses were collected from LILA and brought back to a greenhouse on the Florida Atlantic University campus in Davie, Florida for hatching and rearing. Egg masses were attached to containers with approximately $5 \mathrm{~cm}$ of water and established algal growth. Juvenile $P$. paludosa used in experiments were 1-20 days old. $P$. maculata hatch at a smaller size and were reared for longer (20-40 d old) to become size-matched (in shell length; hereafter SL) with juvenile $P$. paludosa. In 2019 the average initial shell lengths ( $\mathrm{mm} \pm \mathrm{SE}$, means of $n=3$ group means) for $P$. paludosa and $P$. maculata were $3.56 \pm 0.17 \mathrm{~mm}$ and $3.61 \pm 0.09 \mathrm{~mm}$, respectively. In 2020 the average initial shell lengths of $P$. paludosa and $P$. maculata were $4.4 \pm$ $0.1 \mathrm{~mm}$ (mean of $n=4$ group means) and $4.6 \mathrm{~mm} \pm 0.1 \mathrm{~mm}$ (mean of $n=6$ group means) respectively. Initial mean sizes of hatchling $P$. paludosa and juvenile $P$. maculata were not different in either year (t-tests of group means; P-values > 0.45).

In 2019 we stocked the cages with 16 juvenile snails and replicated the intraspecific (16 $P$. paludosa) and interspecific ( $8 P$. paludosa and $8 P$. maculata) treatments six times. We had an additional treatment of 8 juvenile $P$. paludosa $(n=6)$ to compare with higher density treatments to test for density dependent growth but we were primarily interested in effects of invasive snail presence. Two $20.3 \mathrm{~cm}$ pots of planted Eleocharis cellulosa were placed in each cage to serve as 
a substrate for algal resource growth. When placing cages the existing dense emergent vegetation was removed to get the bottoms of the cages flush with the sediment. The Everglades is an oligotrophic (phosphorus limited) ecosystem but removing vegetation disrupted the sediment and probably caused higher nutrient levels (periphyton total phosphorus) in the cages relative to the surrounding slough. We repeated the experiment in 2020 with alterations to make the conditions (i.e., algal nutrients, growth rates, snail densities) more realistic compared with the wetlands where we had been surveying snail assemblages. In 2020 we increased the replication $(n=10)$ and halved the stocked densities $\left(8\right.$ snails $\cdot$ cage $\left.^{-1}\right)$ to reduce the interaction rates. To avoid elevated nutrient levels we placed the cages in a slightly deeper slough (appr. $15 \mathrm{~cm}$ lower in elevation) with sparse vegetation that did not need to be removed. We also eliminated the potted E. cellulosa.

Algal accumulation on the polypropylene ropes was measured as one metric of resource levels (i.e., attached periphyton biomass) among all treatments at the end of each experiment (similar to Dorn 2013). Algae was removed from each unit of rope vegetation by brushing one representative strand (30 cm long) with a toothbrush for 90 seconds and rinsing the rope with up to $400 \mathrm{~mL}$ of deionized water. The algal wash was then filtered onto pre-combusted, pre-weighed A/E glass-fiber filters, dried $\left(103^{\circ} \mathrm{C}\right.$ for at least $\left.24 \mathrm{~h}\right)$, weighed, combusted $\left(500^{\circ} \mathrm{C}\right.$ for $\left.1 \mathrm{~h}\right)$ and reweighed to calculate ash-free dry mass per $\mathrm{cm}^{3}$.

We analyzed total phosphorus in floating periphyton at the end of each experiment as a second test for resource depletion by the invasive snail. Dried periphyton from each replicate was finely ground and analyzed for total phosphorus $\left(\mu \mathrm{g} \cdot \mathrm{g}^{-1}\right.$ periphyton tissue $)$ at the Freshwater Resources Division at Florida International University (Miami, FL).

\section{Chemical Inhibition}


Because the results of our field competition studies were mixed and did not clearly point to a mechanism of resource competition, we conducted two experiments in the lab and one in outdoor mesocosms to test for chemically-mediated inhibition of $P$. paludosa (also see Conner et al. 2008). Snails can interact chemically through mucus trails (Cameron and Carter 1979, Dan and Bailey 1982, Bull et al. 1992) and we first hypothesized these species could interact through mucus avoidance by $P$. paludosa (e.g., inhibition of space use). To test whether $P$. paludosa avoids $P$. maculata mucus we observed juvenile $P$. paludosa habitat use in $38 \mathrm{~L}$ aquariums with the sides conditioned with mucus from different snails. We filled aquariums with $20 \mathrm{~L}$ of pond water and they were kept at ambient summertime temperatures $\left(\sim 30^{\circ} \mathrm{C}\right)$ and aerated throughout the experiment. The aquariums were marked down the center in two equal parts and temporarily divided to establish treatments. Prior to each trial an equal biomass of native Planorbella spp. or invasive $P$. maculata was added to the two sides and allowed to crawl all over their respective sides for $48 \mathrm{~h}$. The distribution of the snails was monitored to make certain that each side had snails crawling on all surfaces. After $48 \mathrm{~h}$ the treatment snails were removed, the divider was removed, and six juvenile ( $\sim 8 \mathrm{~mm} \mathrm{SL})$ P. paludosa were placed in the center of the aquarium. The distribution of snails in the aquarium was monitored every half hour for eight hours producing 16 observations per replicate. The average difference in the $P$. paludosa distributions (\# on each side) was calculated for each replicate trial $(n=11)$.

We also hypothesized that the presence of $P$. maculata, through chemical exudates or waste products might directly inhibit growth of $P$. paludosa even if they do not avoid mucus. To test for direct chemical inhibition of juvenile P. paludosa growth we forced $P$. paludosa to grow in environments (small growth chambers) for 16 days previously conditioned with $P$. maculata chemical cues (i.e., hormones, waste products, mucus). Chambers conditioned with similar-sized 
P. paludosa were employed as controls. Sixty $1 \mathrm{~L}$ growth chambers were filled with $600 \mathrm{ml}$ of pond water filtered through a fish net $\left(60 \mu \mathrm{m}\right.$ mesh) and were aerated and kept in $27^{\circ} \mathrm{C}$ water baths. Growth chambers and food were conditioned with one species of snail or the other and then juvenile $P$. paludosa were grown in those chambers with excess food (romaine lettuce). Growth chambers were assigned one of three conditioning treatments $(n=10$ replicates each): (1) $P$. paludosa-conditioned environment and lettuce, (2) P. maculata-conditioned environment and lettuce, or (3) P. maculata-conditioned environment with lettuce that was conditioned but then then rinsed with pond water (removing visible mucus). Two $P$. paludosa or $P$. maculata (11.8 \pm $0.7 \mathrm{~mm}$ and $12.1 \pm 0.8 \mathrm{~mm} \mathrm{SL}$, initial mean $\pm \mathrm{SD}$, respectively) were placed in the conditioned chambers for $48 \mathrm{~h}$ and fed on the romaine lettuce (1-3 $\mathrm{g}$ wet mass) for $3 \mathrm{~h}$ just prior to their removal. The conditioning snails were removed and individual juvenile $P$. paludosa (initial size $6.89 \pm 0.53$ $\mathrm{mm}$ SL, mean $\pm \mathrm{SE}$ ) were placed into each chamber. Juvenile $P$. paludosa remained in chambers for $48 \mathrm{~h}$ while the conditioning snails were conditioning the next set of growth chambers. This process was repeated eight times over the $16 \mathrm{~d}$ experiment such that every $48 \mathrm{~h}$ the target $P$. paludosa were exposed to fresh cues. All experimental snails were provided more lettuce than could be consumed within $48 \mathrm{~h}$. Each round of conditioning began with fresh pond water from a mesocosm without snails. The target $P$. paludosa were measured several times during the experiment, but we only report the final size and mass gained. One P. paludosa died early in the study (day 4; $P$. maculata treatment) and was replaced with a similar sized snail. The results were unchanged whether or not this individual was included in the analyses therefore we included the results from the substitute snail. Lettuce consumed (initial - final wet mass) was measured after each $48 \mathrm{~h}$ period. Lettuce pieces were blotted dry for $20 \mathrm{~s}$ on paper towel before being measured. To determine whether lettuce consumption rates were affected by conditioning we analyzed mass- 
specific feeding rates of snails during the first six days of the experiment when snails were similar sizes. We calculated the average size (mg dry mass) of each snail during the first six days using the initial and day six measurements (note: sizes were not different between treatments; ANOVA, $\mathrm{P}=0.2)$ and then calculated mass-specific feeding rates (mg total lettuce eaten/mean mg dry mass) were used to test for consumption differences between treatments.

Following the results of the lab study we wanted to determine whether chemical inhibition could possibly be important in the field where P. maculata densities were relatively low $(<0.3$. $\mathrm{m}^{-2}$ ). We forced juvenile $P$. paludosa to grow in outdoor mesocosms filled with $380 \mathrm{~L}$ pond water with variable exposure to adult $P$. maculata. Exposure rates were varied so as to mimic variable (and low) densities of adult $P$. maculata that $P$. paludosa might experience in natural wetlands. To each $1.1 \mathrm{~m}^{2}$ mesocosm we added pond water from a low nutrient pond $\left(<10 \mu \mathrm{g} \cdot \mathrm{L}^{-1}\right)$. We then added $100 \mathrm{mg}$ Osmocote ${ }^{\circledR}$ slow-release fertilizer and $350 \mathrm{mg}$ Miracle Gro® fertilizer (@The Scotts Company LLC, Marysville, Ohio) to create an initial total $\mathrm{P}$ of $\sim 40 \mu \mathrm{g} \cdot \mathrm{L}^{-1}$ in the water and encourage algal growth. Polypropylene ropes were added to each mesocosm as a standardized substrate for algal accumulation. Adult $P$. maculata $(>30 \mathrm{~mm} \mathrm{SL})$ were kept in holding tanks and fed Chara sp., southern naiad (Najas guadalupensis), and other macrophytes. In the gradient analysis we limited movement of the $P$. maculata (exposing $P$. paludosa to mostly water cues) by placing them within wire mesh funnel traps (coated, $1.9 \mathrm{~cm}$ mesh, covering $\sim 0.25 \mathrm{~m}^{2}$ of the bottom) in mesocosms. The cages allowed $P$. maculata to reach the surface but they could not come into contact with the walls or floor of the mesocosm which limited mucus on mesocosm surfaces. Pomacea maculata were added or removed every 2 days to expose juvenile $P$. paludosa to cues at $0,10,20,40,60,80$, and $100 \%$ of time over 40 days (1 September - 11 October 2020). Treatments were replicated twice except for 0,20 , and $100 \%$ exposure ( $n=3$ replicates). An 
additional treatment of $20 \%$ direct exposure was added in which $P$. maculata were freely moving outside of the funnel trap to consider all cues. The treatment was replicated three times to test for total effects of exposure to mucus and waterborne cues of a low density of adult $P$. maculata on juvenile $P$. paludosa. Four juvenile $P$. paludosa were added to each mesocosm. Initial sizes varied from 3.8-12.4 $\mathrm{mm}$ SL but the average in each mesocosm was similar and total biomass did not vary with exposure level $(\mathrm{P}=0.85)$. Juvenile $P$. paludosa were marked with nail polish to distinguish individuals for growth analyses.

\section{Statistical analyses}

We used the Shapiro-Wilk test to test for normality of residuals and Levene's test to confirm homogeneity of variance. Data were log-transformed if assumptions of normality were not met. Analyses of transformed data did not change the interpretation of results, therefore analyses of untransformed data were reported. Snail masses were calculated using length to biomass regressions after shell lengths were measured to the nearest $0.1 \mathrm{~mm}$ (Appendix B). In 2019, the final individual biomass (mean of cage means) of $P$. paludosa from the three treatments were first compared with one-way ANOVA and then analyzed with planned comparisons to test for density dependent growth and competitive interactions. In field experiments final periphyton volume $(\mathrm{mL}), \operatorname{AFDM}\left(\mathrm{mg} \cdot \mathrm{cm}^{-2}\right)$ of periphyton, and total phosphorus $\left(\mu \mathrm{g} \cdot \mathrm{g}^{-1}\right.$ periphyton tissue) were statistically compared between all treatments with one-way ANOVA in 2019 and with t-tests between the two competition treatments in 2020 . In the lab study of snail mucus avoidance a onesample two-tailed t-test with a null expectation zero difference (i.e., no preference) was used to determine whether the $P$. paludosa response demonstrated any preference. Analyses of individual exposure treatment on snail biomass gain (final-initial dry mass) in the lab and mass-specific consumption rates (first six days) were conducted with one-way ANOVAs and post-hoc Tukey 
tests. In the mesocosm study the initial sizes of juvenile $P$. paludosa varied substantially such that individual growth was strongly size-dependent. We analyzed residual growth after adjusting for size differences of individual snails; we regressed juvenile $P$. paludosa instantaneous growth [ln(final mass)- $\ln$ (initial mass)] against initial mass (dry $\mathrm{mg}$ ). We used linear regression analysis to test for effects of exposure rates (i.e., to caged $P$. maculata) on average residual growth in each mesocosm and one-way ANOVA to test for treatment effects of $0 \%$ exposure, $20 \%$ water exposure, or $20 \%$ direct exposure ( $n=3$ reps per treatment) on average residual growth and algal accumulation (i.e., resource availability).

\section{Results}

Apple snail assemblages at LILA

No P. maculata were collected in 448 throw traps conducted from 2009-2012 (Fig. 1a), but from 2018-2020 P. maculata has dominated the assemblage making up >80\% of the total Pomacea spp. captures (Fig. 1a; 280 throw traps). The average Pomacea spp. densities were low in LILA (mean \pm temporal standard deviation; $0.06 \mathrm{~m}^{-2} \pm 0.06, n=8$ estimates) from 2009-2012, but were generally $>0.1 \mathrm{~m}^{-2}$ when sampling resumed after the invasion of $P$. maculata (2018-2020; mean: $0.20 \mathrm{~m}^{-2} \pm 0.15, n=5$ estimates $)$.

The egg mass survey conducted in 2014 indicated that $P$. maculata was present and reproducing in all LILA wetlands (Fig. 1b), but that $P$. paludosa was still present in all wetlands and dominated the egg mass composition in all macrocosms except M4. The proportion of all egg masses that were P. maculata increased from 2014 to 2019 and 2020 in three of the four wetlands. Pomacea maculata dominated (>60\%) the composition of observed egg masses in all wetlands except M2 (Fig. 1b) for 2019 to 2020 and no P. paludosa egg masses were observed in M4 in 2019 or 2020 (Fig. 1c). 


\section{Testing for Competition in the Field}

Survival of both $P$. paludosa and P. maculata in field experiments was high in both years across all treatments $(75-100 \%$, average $=96.7 \%$ per cage $)$. In $2019 P$. paludosa growth varied by treatment $\left(\mathrm{F}_{2,15}=5.79, \mathrm{P}=0.01\right)$. Pomacea paludosa final size was significantly smaller in high density cages (planned contrast $\mathrm{t}=2.3, \mathrm{P}=0.035$, data not shown) and when controlling for density the presence of $P$. maculata significantly reduced $P$. paludosa final size $($ Fig. $2 \mathrm{a} ; \mathrm{t}=2.5, \mathrm{P}=$ 0.025); juvenile $P$. paludosa were $27 \%$ smaller in cages with $P$. maculata. Juvenile $P$. paludosa gained $391.9 \mathrm{mg}$ in the conspecific treatment stocks with 16 snails and grew $15.4 \mathrm{~mm}$ (from 3.6 to $19.0 \mathrm{~mm})$ over 5 weeks $\left(3.1 \mathrm{~mm} \cdot \mathrm{wk}^{-1}\right)$. Final floating periphyton mat volume $(\mathrm{mL})$ was not different among all treatments $\left(\mathrm{F}_{2,15}=2.14, \mathrm{P}=0.152\right)$. Average algal AFDM on polypropylene ropes was $0.54 \pm 0.05 \mathrm{mg} \cdot \mathrm{cm}^{-2}( \pm \mathrm{SE})$ across all treatments and did not differ between treatments $\left(\mathrm{F}_{2,15}=0.01, \mathrm{P}=0.9\right)$. Average periphyton total phosphorus was $286.9 \pm 11.4 \mu \mathrm{g} \cdot \mathrm{g}^{-1}$ and did not differ among all treatments $\left(\mathrm{F}_{2,14}=0.34, \mathrm{P}=0.7\right)$.

In the 2020 experiment $P$. maculata did not affect $P$. paludosa final size (Fig. $2 \mathrm{~b} ; \mathrm{t}=0.20$, $\mathrm{P}=0.84$ ). Snails gained $186.6 \mathrm{mg}$ in the intraspecific treatment stocked with eight snails and grew $10.2 \mathrm{~mm}$ (4.4 to $14.6 \mathrm{~mm})$ over 5 weeks $\left(2 \mathrm{~mm} \cdot \mathrm{wk}^{-1}\right)$. There was no difference in final floating periphyton mat volume $(\mathrm{t}=-0.69, \mathrm{P}=0.50)$ or $\mathrm{AFDM}$ on the artificial vegetation $(\mathrm{t}=0.15, \mathrm{P}=$ 0.88). Compared to 2019 the average algal AFDM was $35 \%$ lower in $2020\left(0.38 \pm 0.02 \mathrm{mg} \cdot \mathrm{cm}^{-}\right.$

${ }^{2}$, average \pm SE). Despite starting at slightly larger sizes in 2020, and being stocked with lower densities the average final P. paludosa and P. maculata biomasses were $30 \%$ smaller.

\section{Chemical Inhibition}

Juvenile $P$. paludosa showed no habitat selection when given a choice of habitats conditioned by P. maculata or native Planorbids $(\mathrm{t}=0.58, \mathrm{~N}=11, \mathrm{P}=0.57)$. In the lab growth study, all P. paludosa 
fed and grew, but growth was 53\% lower with P. maculata conditioning (Fig. 3; $\mathrm{F}_{2,27}=24.9, \mathrm{P}<$ 0.001). Mass-specific consumption rates on lettuce were similar among treatments at day six of the experiment, when snails were still similar sizes $\left(\mathrm{F}_{2,27}=1.0, \mathrm{P}=0.4\right)$. Pomacea paludosa grew significantly slower in P. maculata-conditioned chambers compared to P. paludosa-conditioned chambers regardless of lettuce rinsing (Tukey's P-values $<0.001$ ) and there was no effect of lettuce rinsing on P. paludosa growth in the P. maculata-conditioned chambers $(\mathrm{P}=0.98)$.

In the mesocosm study individual $P$. paludosa instantaneous growth was correlated with initial mass in both the mesocosm exposure gradient analysis $\left(\mathrm{R}^{2}=0.54, \mathrm{P}<0.001\right)$ and the analysis of total cue effects $\left(\mathrm{R}^{2}=0.11, \mathrm{P}=0.05\right)$. Mean residual growth (size adjusted) in a mesocosm was negatively correlated with exposure to caged $P$. maculata $\left(\right.$ Fig. $4 \mathrm{a} ; \mathrm{R}^{2}=0.35, \mathrm{P}=$ 0.01 ) with most negative residuals produced at $\geq 60 \%$ exposure. The growth of snails in low total (waterborne and direct cue) exposure (20\%, uncaged P. maculata), when contrasted with the control (no exposure) and 20\% indirect exposure (caged P. maculata) suggested P. paludosa growth may be reduced further upon direct exposure to mucus, but the P-value was non-significant (Fig. 4b; F2,6 $=4.5, \mathrm{P}=0.06$ ). Average algal AFDM on polypropylene ropes was $0.05 \pm 0.01 \mathrm{mg}$. $\mathrm{cm}^{-2}( \pm \mathrm{SD})$ and the algal biomass accumulated in the direct exposure treatment was not different from the other two treatments $\left(\mathrm{F}_{2,6}=0.27, \mathrm{P}=0.77\right)$.

\section{Discussion}

The results of this work implicate chemical antagonism as a potentially important mechanism of interaction between gastropods in an ongoing invasion in southern Florida wetlands. We documented an invasion of four oligotrophic freshwater wetlands by P. maculata and the coincident local extinction of the native congeneric P. paludosa in one of the wetlands. This is the first reported local extinction of $P$. paludosa correlated with the invasion by $P$. maculata. Previous 
lab studies suggested asymmetric competition could produce eliminations of P. paludosa (Conner et al. 2008, Posch et al. 2013), however until this work the mechanisms of interactions between the snails were unclear and had only been investigated in the lab. We believe the results of this study point to chemical antagonism as a potentially new direction for investigations of interference between competitors and invasions of animals generally and might explain why P. paludosa distributions appear to recede with invasions of P. maculata in Florida (Rawlings et al. 2007, Dorn and Hafsadi 2016, Gutierre et al. 2019).

Members of the Ampullariidae family which includes Pomacea species are successful invaders in many parts of the world (Rawlings et al. 2007, Horgan et al. 2014) and are listed among the world's worst invasive species (Lowe et al. 2000). Our study documented the apple snail species composition at LILA shifting from P. paludosa-only to $P$. maculata-dominated wetlands over a six-year period. Pomacea paludosa was the only apple snail species in throw trap samples from 2009-2012 and we have no memory of finding P. maculata egg masses in the wetlands although they were found in some of the peripheral ditches and small canals outside the levees by 2012 (N. Dorn, pers. obs.). The absence of P. maculata in throw traps through summer 2012 and the presence of $P$. maculata egg masses, and therefore reproductive $P$. maculata adults, in every LILA wetland in September 2014 indicates invasion of the wetlands occurred between the latter half of 2012 and the summer of 2014. The composition of observed egg masses and the composition in throw traps from 2018-2020 collectively indicated a P. maculata-dominated composition at LILA from 2018-2020. The rapid establishment at LILA is consistent with others documenting sudden P. maculata establishment shortly after signs of invasion (egg mass observations) in other parts of Florida (Rawlings et al. 2007, Gutierre et al. 2019). 
Some Ampullarids introductions have eliminated native snail populations and have even been used as biological controls of native snail hosts of schistosomes (Jobin et al. 1973, Nguma et al. 1982, Pointier et al. 1991). Although there have been suggestions that P. maculata might displace P. paludosa in Florida (Rawlings et al. 2007) and suggestions of negative correlations in the field (Dorn and Hafsadi 2016), this is the first reported displacement coinciding with invasion. Two consecutive years of egg mass surveys ( $n=16$ surveys), five throw trapping sessions ( $n=58$ throws across sloughs and ridges), and additional egg mass surveys in other habitats indicated a complete local extinction of P. paludosa in M4. Pomacea paludosa egg masses were also quite uncommon in M1 and it seems they could disappear from that wetland within the next few years. At the first invasion site in Florida, native $P$. paludosa were completely absent in throw traps in years immediately following $P$. maculata invasion, however native snail densities were nearly undetectable just prior to invasion, therefore the role of $P$. maculata invasion could not be clearly causally linked to local extinction of $P$. paludosa (Gutierre et al. 2019). In our wetlands the native snails were found in every macrocosm prior to invasion and remained in every macrocosm immediately after invasion (see Fig. 1) indicating a period of local overlap before P. paludosa went extinct.

Competition is generally held to have strong impacts among herbivores (Gurevitch et al. 1992) and among herbivorous gastropods (Brown 1982, Cross and Benke 2002) and competitive displacement of native snails by invasive snails has been reported (Pointier et al. 1991, Pointier and David 2004, Byers 2000). Interspecific competition would seem to be a natural hypothesis for explaining displacements, but snails engage in a variety of interspecific interactions (e.g., interspecific egg predation; Turner et al. 2007), making the exact mechanism responsible for displacement impossible to identify using field data alone. In our 2019 field experiment we 
found evidence for growth inhibition of $P$. paludosa when half of the neighboring snails were $P$. maculata, but we did not identify any evidence for increased resource limitation by $P$. maculata . Depletion of resources is necessary to implicate exploitative resource competition and we know from the two field experiments that algal productivity was broadly correlated with Pomacea spp. growth rates (i.e., 2019 had 35\% greater algal accumulation and 30\% greater growth of both species). Furthermore previous studies in mesocosms demonstrated that nutrient additions had direct effects on growth of both species (Davidson and Dorn 2018). Nevertheless, the growth limitation in 2019 could not be explained with exploitative competition because no resource was reduced; algal biomass, floating metaphyton volume, and nutrient (phosphorus) levels were equal.

Competition without resource depletion between the two apple snails could still have occurred through avoidance behavior (i.e., interference) and less movement of P. paludosa if they avoided habitats that had become covered in mucus of $P$. maculata. Although gastropods are known to interact through mucus trails (Davies and Blackwell 2007) and some species move away from waterborne chemical cues of invasive gastropods (Raw et al. 2013), we did not find evidence that juvenile P. paludosa avoided habitats where juvenile $P$. maculata have crawled. Our observations in the lab also did not indicate any regular change in behavior when the two species came into contact (D. Drumheller, pers. obs.). In lab experiments the presence of an invasive marine snail (Littorina littorea) as well as exposure to their waterborne cues reduced herbivory by the native snail (L. obtusa; Putnam and Peckol 2018). However, the growth inhibition observed in our experiments cannot be interpreted as a feeding inhibition because feeding rates were similar across treatments at day six of the lab chamber experiment when snails were similar sizes. When taken altogether the results of our field experiments and lab 
experiments do not implicate resource competition or interference competition, but suggest interspecific chemical inhibition by invasive snails as a potentially important mechanism for reduced native snail recruitment.

Overall, the field experiments showed mixed evidence for the importance of interactions between the species. When we minimized disturbance of the sediments around the cages in the 2020 cage study the snails grew more slowly and all evidence for growth inhibition by $P$. maculata neighbors disappeared. We suggest the variable results could have been caused by the differences in size or biomass of $P$. maculata in each field study and that the degree of growth inhibition likely depends on total biomass of the invasives or size asymmetry (i.e., juvenile exposure to relatively larger $P$. maculata). Higher nutrients and faster algal growth resulted in $340 \%$ more massive $P$. maculata in the heterospecific cages in 2019 than to 2020 (mean of cage means \pm SD; $1127.4 \pm$ $198 \mathrm{mg}$ and $330.4 \pm 255.3$, respectively). The size (mass:mass) ratio of $P$. maculata to $P$. paludosa individuals at the termination of the cage study in 2019 was 3.9, but in 2020 it was only 1.7 . In the growth chamber and mesocosm experiments the conditioning P. maculata were 3.6 times and $>8$ times the initial individual $P$. paludosa biomass, respectively. Therefore, the absence of a growth inhibiting effect only occurred when $P$. maculata remained $<2$ times the individual biomass of $P$. paludosa or when exposure to waterborne cues was $<60 \%$. In previous lab experiments adult $P$. maculata decreased juvenile $P$. paludosa growth and one adult $P$. maculata had the same lethal effect as one adult $P$. paludosa on juvenile $P$. paludosa through unknown mechanisms (Conner et al. 2008). Significant growth inhibition in the field only occurred when snail densities were high and productive conditions increased the size asymmetry between the species. We surmise that either the asymmetry or the total invasive snail biomass could have been responsible for the inhibiting effects in 2019. 
Collectively, our experiments show that the constant exposure to some chemical that $P$. paludosa did not clearly avoid seemed to reduce their growth. Growth inhibition by chemical cues could explain results in previous lab experiments where $P$. maculata presence reduced the growth of P. paludosa but the snails were fed ad libitum (Conner et al. 2008, Posch et al. 2013). In high density tanks Posch et al. (2013) found that increasing ratios of juvenile $P$. maculata to juvenile $P$. paludosa reduced native snail growth. Conner et al. (2008) found that juvenile P. paludosa experienced significantly lower growth and survival in the presence of adult P. maculata. The identity of the cues causing the growth reduction remains unknown and will require further investigation, but it appears it cannot simply be caused by general waste products (i.e., ammonia) as the lab controls included P. paludosa conditioning with snails of similar sizes. Together, the results show that without exploitative competition, or interfering with snail movement or feeding and without controlling for effects of snail waste products, P. maculata presence culminates in negative effects on P. paludosa growth. The mesocosm experimental results indicated that part of the growth inhibition is present in the water and additional inhibition probably comes by contact with mucus on surfaces.

The results of the lab chemical inhibition experiment were interesting but were performed at high densities/exposures and could not be expected to be important in the field at our wetlands (LILA) or elsewhere unless they were appropriately scaled to field conditions and densities. The outdoor mesocosm experiments showed that increasing exposure to just the waterborne cues of a single adult $P$. maculata significantly reduced juvenile $P$. paludosa growth. Mesocosm areas were $1.1 \mathrm{~m}^{2}$ and therefore encounter rates approximated densities $\left(\mathrm{m}^{-2}\right)$, such that a treatment of $20 \%$ exposure was similar to an expected natural encounter with randomly distributed adult Pomacea maculata at a density of $0.18 \cdot \mathrm{m}^{-2}$ (consider densities in Fig. 1a). Mesocosm experiments showed 
that $\geq 60 \%$ exposure to waterborne cues of a single adult $P$. maculata reduced juvenile $P$. paludosa growth, but those relatively higher Pomacea densities $\left(>0.6 \mathrm{~m}^{-2}\right)$ were not found in LILA and can be relatively uncommon in published literature from the Everglades where $P$. maculata has invaded (Gutierre et al. 2019). Nevertheless, part of the inhibition is in the water and therefore may be possible that $P$. maculata could inhibit juvenile $P$. paludosa through waterborne cues alone where the two species coexist at higher densities. Native juvenile snail growth in mesocosms may be further reduced when exposed to adult invasive snail mucus and waterborne cues at just $20 \%$ exposure, although this result was not significant. The nonsignificant statistical result was influenced by the low replication and high variability and therefore low power of the experiment ( $n=3, \beta=0.33$ ). We suggest low densities (exposures) of adult $P$. maculata might reduce $P$. paludosa growth through an unidentified growth-inhibiting chemical in the water and on surfaces and that this mechanism requires greater scrutiny among gastropods and especially among the invasive Ampullaridae.

Several studies point to the importance of resource competition among gastropods (Brown 1982, Osenberg 1989, Byers 2000), while chemical inhibition has not been well studied. To our knowledge this is the first empirical study demonstrating reduced growth of an herbivorous gastropod in response to interspecific chemical cues of another species. There is a lack of investigation of chemical growth inhibition among animals in the literature and most studies investigating chemical inhibition are older and focused on intraspecific interactions and crowded conditions (e.g., Berrie and Visser 1963, Thomas et al. 1975). More recently, lab experiments with the non-native marine gastropod Littorina littorea found lower grazing rates of a native gastropod (L. obtusata; Putnam and Peckol 2018) in response to waterborne cues, which is a kind of interference competition. In our study feeding rates were unaffected by P. maculata cues. A recent 
study of flour beetles (Tribolium spp.) demonstrated that increasing intensity of chemical conditioning by one species reduced egg laying of a congener, but development time was actually hastened (Bullock et al. 2020). The direct chemical effects of the flour beetle interaction may be more similar to what we observed with Pomacea spp. In contrast to the heavy mechanistic dependence on competitive mechanisms in the literature our results point to a direct interspecific inhibition (i.e., not interference for resources) that could be important even at low densities. Chemical inhibition may be confounded with competition in studies of antagonism between species and could help explain results from studies where asymmetric growth inhibition were not accompanied by resource depletion (e.g., Riley et al. 2008). More studies should investigate chemical interactions as a potential mechanism for interspecific antagonism among gastropods and invertebrates in general, and particularly as a means of exclusion or suppression of native species. Identification of the chemical substance and demonstration of the taxonomic scope and spatiotemporal scale of inhibition effects in wetlands like the Everglades will all require additional investigation.

The results of previous studies combined with our work suggest that increasing establishment of invasive $P$. maculata populations across Florida could negatively affect $P$. paludosa populations. Florida apple snail sexual maturity is size dependent (Hanning 1979) and mortality to juvenile predators is also size dependent (Davison and Dorn 2018), therefore reductions in growth to adulthood may negatively impact their reproductive output and recruitment. Additionally, Florida wetlands experience dry conditions seasonally and juvenile $P$. paludosa survival is significantly lower than larger sized snails during dry down conditions (Darby et al. 2008). Together these results suggest that reductions in growth by established $P$. maculata populations may negatively impact $P$. paludosa populations. Interactions between these two 
species, and the strength of their interactions in field settings, should be more carefully investigated. Although $P$. paludosa has been locally excluded from a relatively small ( 8 ha) wetland at LILA we cannot determine how generalizable the result might be. Furthermore, there seem to be examples of coexistence of the species in the Everglades over at least four years post invasion (see Gutierre et al. 2019). Finally, even if chemical antagonism does deplete P. paludosa in some times and places the potential for coexistence in some wetlands might be enhanced by selective predators, like crayfish (Procambarus spp.) that preferentially consume juvenile $P$. maculata (Hafsadi and Dorn 2016, Davidson and Dorn 2018). The Everglades populations of $P$. paludosa should continue to be carefully monitored to better understand the potential for coexistence or exclusion in natural wetlands.

We reported the first demonstration of displacement of $P$. paludosa coincident with $P$. maculata invasion in an 8-hectare wetland. Experiments in the field, lab, and outdoor mesocosms all suggested that the mechanism of interaction between the species was not competition (exploitative or interference). Instead we demonstrated a rarely observed chemical inhibition of growth by both juvenile and adult $P$. maculata and suggest that the strength of cues by adult $P$. maculata might be important at field scales even given the naturally low snail densities. Our results point to little studied chemical mechanisms (i.e., direct inhibition) that might be important in other cases where growth inhibition can be demonstrated without resource reduction (Conner et al. 2008, Riley et al. 2008). This study adds to the diversity of interactions between gastropods and points to the need to further investigate the chemicals involved in these interactions. 

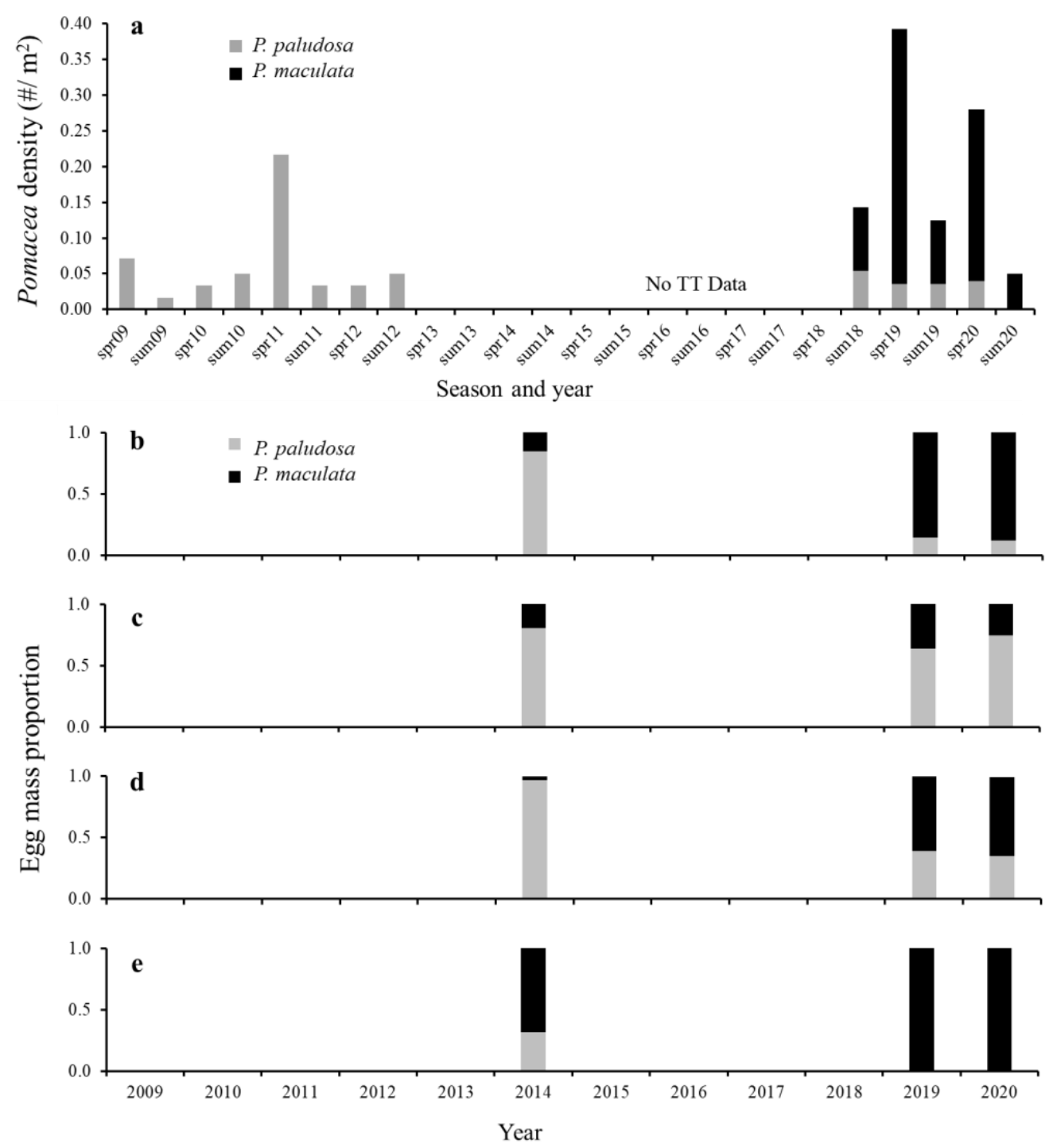

Fig. 1 Apple snail species assemblages in LILA wetlands from a average apple snail (Pomacea spp.) densities estimated from throw trap sampling of sloughs (M1-M4) from 2009 to 2020 and be composition of observed $P$. maculata and P. paludosa egg masses on emergent vegetation from $2014(n=1), 2019(n=7)$, and $2020(n=9)$ surveys in M1-M4 (b-e). Spring throw trap samples were typically collected in Feb-March and summer samples were collected in July. Means of the species are stacked. In 2009-2012 $n=15$ traps wetland ${ }^{-1}$ were collected (in March 2009 only M3 and M4 were sampled, $n=14$ traps wetland $^{-1}$ ) and from 2018-2020 14 traps wetland $^{-1}$ were collected. No surveying occurred in years without egg mass proportion data 


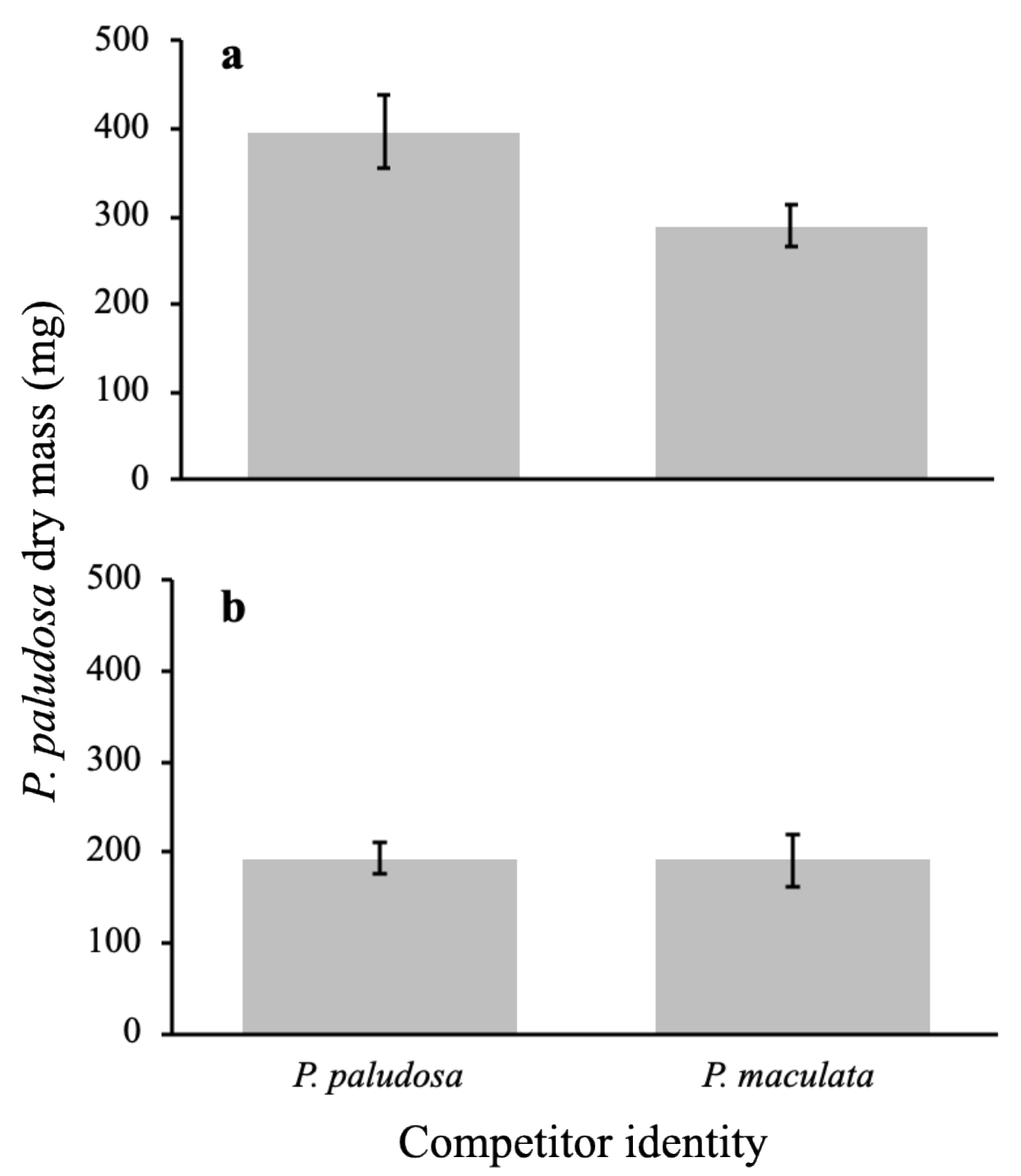

Fig. 2 Mean ( \pm SE) juvenile Pomacea paludosa biomass (mg dry mass) after five weeks growing in experimental field cages placed in wetlands at the Loxahatchee Impoundment Landscape Assessment. Small juvenile snails (3.6-4.4 mg) were stocked into conspecific (only P. paludosa) or heterospecific cages (half P. maculata) using a replacement experimental design. In 2019 a the 1- $\mathrm{m}^{2}$ cages had either 16 P. paludosa or eight $P$. paludosa plus eight $P$. maculata $(n=6$ replicates). In 2020 b experimental cages had either eight P. paludos $a$ or four P. paludosa plus four $P$. maculata $\cdot \mathrm{m}^{-2}(n=10$ replicates $)$ 


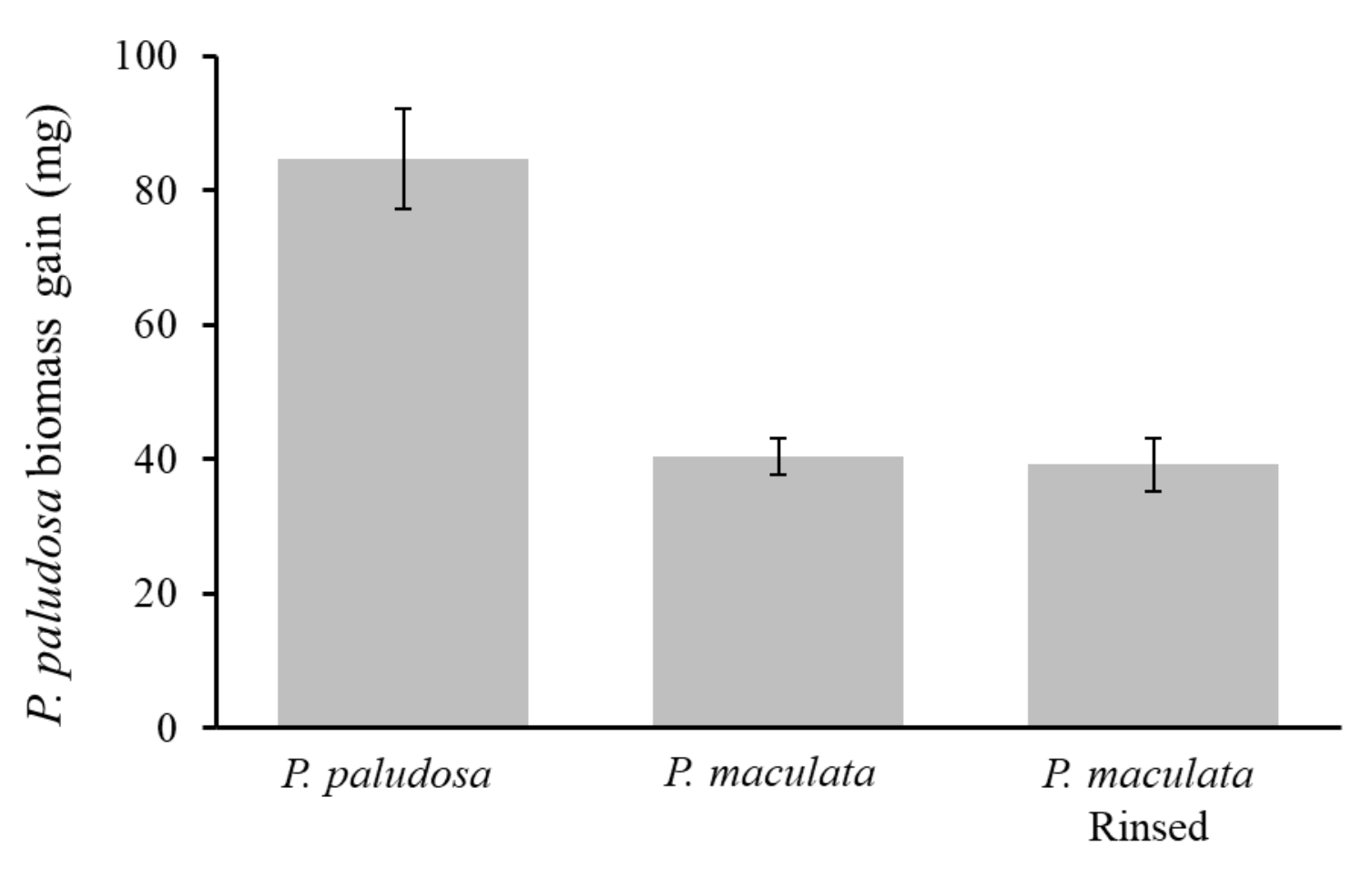

Conditioning Treatment

Fig. 3 Mean juvenile P. paludosa growth (final - initial mass) after 16 d growing in chambers with different conditioning treatments. Chambers and food (romaine lettuce) were conditioned with conspecific chemical cues or invasive P. maculata cues. In the third treatment the lettuce was rinsed after conditioning to remove obvious mucus. Chambers were rotated every two days to keep the cues fresh. Each treatment was replicated ten times. Initial snail biomass was $26.2 \pm$ $1.0 \mathrm{mg}$ (mean $\pm \mathrm{SE}$ ). Error bars represent one standard error 

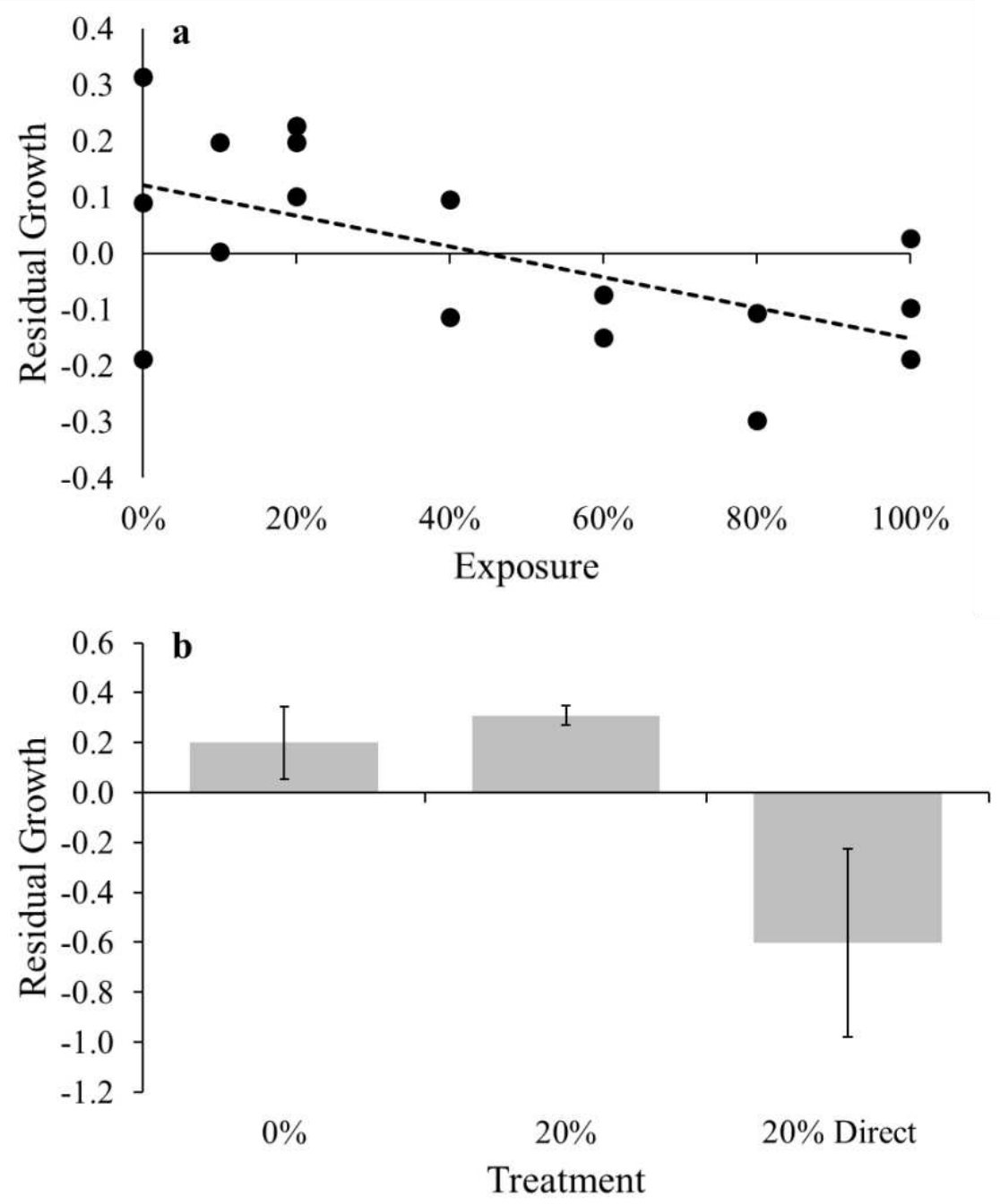

Fig. 4 Mean juvenile $P$. paludosa growth (residual growth) as a function of exposure to adult $P$. maculata waterborne cues (i.e., amount of time a caged P. maculata was present) (a) or waterborne cues and mucus (20\% direct) (b). Residual growth in each panel represents the mesocosm mean residuals taken from regressions of instantaneous individual growth [ln(final mass)-ln(initial mass)] against initial mass. Mean residual growth for individual mesocosms are shown in $\mathbf{a}$. In panel $\mathbf{b}$ the averages of three replicate mesocosms $(n=3$, error bars show standard error) was plotted (no exposure, 20\% waterborne cues only, 20\% waterborne cues plus mucus) 


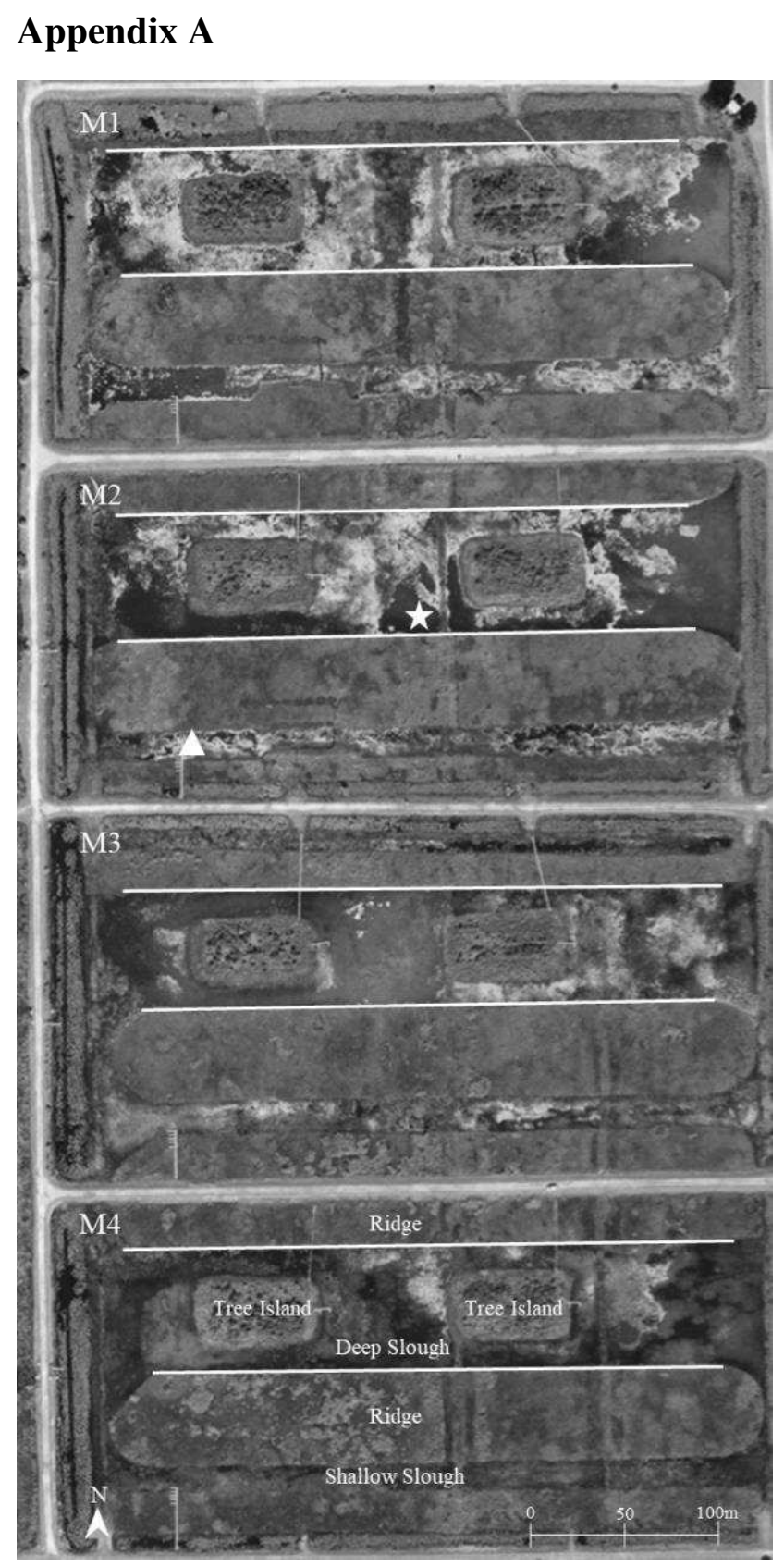

Fig. A1 Aerial image of the four 8-ha replicate wetlands at the Loxahatchee Impoundment Landscape Assessment. Wetlands are arranged M1-M4 from north to south. Each wetland contains tree islands, ridges, and sloughs (labeled in M4). The ridge elevations are $30.5-48.8 \mathrm{~cm}$ higher than the sloughs. Throw trap sampling was conducted in the sloughs of each wetland. Surveys of egg masses (white lines) occurred on the ridge-slough interface. Cage locations from field experiments in M2 are denoted by a triangle (2019) and a star (2020) 


\section{Appendix B}

Table B1 Linear regression results for total dry mass (mg; sum of dry weights of somatic tissue, operculum, and shell) as a function of shell length for both $P$. paludosa and $P$. maculata.

Variables were transformed for linearity using the natural logarithm. Number of snails used for each regression and shell length $(\mathrm{mm})$ ranges are also listed

\begin{tabular}{l|l|l|l|l|l} 
Species & $\mathrm{n}$ & Range (mm SL) & Slope & Intercept & $\mathrm{R}^{2}$ \\
\hline P. paludosa & 73 & $3.44-31.6$ & 2.64 & -1.84 & 0.98 \\
\hline P. maculata & 59 & $3.55-36.48$ & 2.69 & -2.18 & 0.97
\end{tabular}




\section{References}

Barnes, M.A., R.K. Fordham, and R.L. Burks. 2008. Fecundity of the exotic applesnail, Pomacea insularum. Freshwater Science 27:738-745.

Bellard, C., P. Cassey, and T.M. Blackburn. 2016. Alien species as a driver of recent extinctions. Biology letters 12:20150623.

Berrie, A.D. and S.A. Visser. 1963. Investigations of a growth-inhibiting substance affecting a natural population of freshwater snails. Physiological Zoology 36:167-173.

Brönmark, C. and L.A. Hansson. 2000. Chemical communication in aquatic systems: an introduction. Oikos 88:103-109.

Brönmark, C. and L.B. Pettersson. 1994. Chemical cues from piscivores induce a change in morphology in crucian carp. Oikos 70:396-402.

Brown, K.M. 1982. Resource overlap and competition in pond snails: an experimental analysis. Ecology 63:412-422.

Bull, C.M., G.H. Baker, L.M. Lawson, and M.A. Steed. 1992. Investigations of the role of mucus and faeces in interspecific interactions of two land snails. Journal of Molluscan Studies 58:433-441.

Bullock, M., G. Legault, and B.A. Melbourne. 2020. Interspecific chemical competition between Tribolium castaneum and Tribolium confusum (Coleoptera: Tenebrionidae) reduces fecundity and hastens development time. Annals of the Entomological Society of America 113:216-222.

Burks, R.L. and D.M. Lodge. 2002. Cued in: advances and opportunities in freshwater chemical ecology. Journal of chemical ecology 28:1901-1917.

Byers, J.E. 2000. Competition between two estuarine snails: Implications for invasions of exotic species. Ecology 81:1225-1239.

Cameron, R.A.D. and M.A. Carter. 1979. Intra- and interspecific effects of population density on growth and activity in some helicid land snails (Gastropoda: Pulmonata). Journal of Animal Ecology 48:237-246.

Cattau, C.E., J. Martín, and W.M. Kitchens. 2010. Effects of an exotic prey species on a native specialist: example of the snail kite. Biological Conservation 143:513-520.

Cattau, C.E., P.C. Darby, R.J. Fletcher, and W.M. Kitchens. 2014. Reproductive responses of the endangered snail kite to variations in prey density. Journal of Wildlife Management 78:620-631.

Conner, S.L., C.M. Pomory, and P.C. Darby. 2008. Density effects of native and exotic snails on growth in juvenile apple snails Pomacea paludosa (Gastropoda: Ampullariidae): a laboratory experiment. Journal of Molluscan Studies 74:355-362.

Croll, R.P. 1983. Gastropod chemoreception. Biological Reviews 58:293-319.

Cross, W.F. and A.C. Benke. 2002. Intra-and interspecific competition among coexisting lotic snails. Oikos 96:251-264.

Crowl, T.A. and A.P. Covich. 1990. Predator-induced life-history shifts in a freshwater snail. Science 247:949-951.

Dan, N. and S.E.R. Bailey. 1982. Growth, mortality, and feeding rates of the snail Helix aspersa at different population densities in the laboratory, and the depression of activity of helicid snails by other individuals, or their mucus. Journal of Molluscan Studies 48:257-265.

Darby, P.C., R.E. Bennetts, and H.F. Percival. 2008. Dry down impacts on apple snail (Pomacea paludosa) demography: implications for wetland water management. Wetlands 28:204-214.

Davidson, A.T. and N.J. Dorn. 2018. System productivity alters predator sorting of a size-structured mixed prey community. Oecologia 186:1101-1111. 
Davies, M. and Blackwell, J. 2007. Energy saving through trail following in a marine snail. Proc. R. Soc. Lond. B 274:1233-1236.Darby, P.C., R.E. Bennetts, and H.F. Percival. 2008. Dry down impacts on apple snail (Pomacea paludosa) demography: implications for wetland water management. Wetlands 28:204.

Davis, M.A. 2003. Biotic globalization: does competition from introduced species threaten biodiversity?. Bioscience 53:481-489.

Didham, R.K., J.M. Tylianakis, M.A. Hutchison, R.M. Ewers, and N.J. Gemmell. 2005. Are invasive species the drivers of ecological change?. Trends in ecology \& evolution 20:470-474.

Dodson, S. 1988. The ecological role of chemical stimuli for the zooplankton: Predator-avoidance behavior in Daphnia. Limnology and Oceanography 33:1431-1439.

Doherty, T.S., A.S. Glen, D.G. Nimmo, E.G. Ritchie, and C.R. Dickman. 2016. Invasive predators and global biodiversity loss. Proceedings of the National Academy of Sciences 113:11261-11265.

Dorn, N. J. and M. I. Cook. 2015. Hydrological disturbance diminishes predator control in wetlands. Ecology 96: 2984-2993.

Dorn, N.J. and M. Hafsadi. 2016. Native crayfish consume more non-native than native apple snails. Biological Invasions 18:159-167.

Dorn, N. J., R. Urgelles and J. C. Trexler. 2005. Evaluating active and passive sampling methods to quantify crayfish density in a freshwater marsh. Journal of the North American Benthological Society 24:346-356.

Drumheller, D.K. 2020. Population limitations of the Florida apple snail (Pomacea paludosa). Thesis, Florida Atlantic University, Boca Raton, USA.

Fogarty, M.J. and J.D. Albury. 1967. Late summer foods of young alligators in Florida. Proceedings of the Southeastern Association of Game and Fish Commissioners. 21:220-222.

Gaiser, E.E., J.C. Trexler, and P.R. Wetzel. 2012. The Florida Everglades. In: Batzer DP, Baldwin AH (eds) Wetland habitats of North America: ecology and conservation concerns. University of California Press, Berkely, pp 231-252.

Gurevitch, J. and D.K. Padilla. 2004. Are invasive species a major cause of extinctions?. Trends in ecology \& evolution 19:470-474.

Gurevitch, J., L.L. Morrow, A. Wallace, and J.S. Walsh. 1992. A meta-analysis of competition in field experiments. The American Naturalist 140:539-572.

Gutierre, S. M., P. C. Darby, P. L. Valentine-Darby, D. J. Mellow, M. Therrien, and M. Watford. 2019. Contrasting Patterns of Pomacea maculata Establishment and Dispersal in an Everglades Wetland Unit and a Central Florida Lake. Diversity 11:183.

Hanning, G.W. 1979. Aspects of reproduction in Pomacea paludosa (Mesogastropoda: Pilidae). M.S. Thesis, Florida State University, Tallahassee, FL.

Hierro, J.L. and R.M. Callaway. 2003. Allelopathy and exotic plant invasion. Plant and soil 256:29-39.

Holway, D.A. 1999. Competitive mechanisms underlying the displacement of native ants by the invasive Argentine ant. Ecology 80:238-251.

Horgan, F.G., A.M. Stuart, and E.P. Kudavidanage. 2014. Impact of invasive apple snails on the functioning and services of natural and managed wetlands. Acta Oecologica 54:90-100.

Jobin, W.R., F.F. Ferguson, and L.A. Berrios-Duran. 1973. Effect of Marisa cornuarietis on populations of Biomphalaria glabrata in farm ponds of Puerto Rico. The American journal of tropical medicine and hygiene 22:278-284. 
Kawata, M. and H. Ishigami. 1992. The growth of juvenile snails in water conditioned by snails of a different species. Oecologia 91:245-248.

Kiesecker, J.M., A.R. Blaustein, and C.L. Miller. 2001. Potential mechanisms underlying the displacement of native red-legged frogs by introduced bullfrogs. Ecology 82:1964-1970.

Kyle, C. H., A. L. Plantz, T. Shelton and R. L. Burks. 2014. Count your eggs before they invade: identifying and quantifying egg clutches of two invasive apple snail species (Pomacea). PLOS One 9:e99149.

Levy, M.G., M. Tunis, and H. Isseroff. 1973. Population control in snails by natural inhibitors. Nature 241:65-66.

Lowe, S., M. Browne, S. Boudjelas, and M. De Poorter. 2004. 100 of the World's worst invasive alien species. A selection from the Global Invasive Species Database. The Invasive Species Specialist Group (ISSG) a specialist group of the Species Survival Commission (SSC) of the World Conservation Union (IUCN).

Maida, M., P.W. Sammarco, and J.C. Coll. 1995. Effects of soft corals on scleractinian coral recruitment. I: Directional allelopathy and inhibition of settlement. Marine Ecology Progress Series 121:191202.

Marzolf, N., S. Golladay, P. McCormick, A. Covich, and S. Wilde. 2018. Inter- and intra-annual apple snail egg mass dynamics in a large southeastern US reservoir. Hydrobiologia 811:155-171.

Mooney, H.A. and E.E. Cleland. 2001. The evolutionary impact of invasive species. Proceedings of the National Academy of Sciences 98:5446-5451.

Nguma, J.F.M., F.S. McCullough, and E. Masha. 1982. Elimination of Biomphalaria pfeifferi, Bulinus tropicus and Lymnaea natalensis by the ampullarid snail, Marisa cornuarietis, in a man-made dam in northern Tanzania. Acta tropica 39:85-90.

O'Hare, N.K. 2010. Pomacea paludosa (Florida Apple Snail) reproduction in restored and natural seasonal wetlands in the Everglades. Wetlands 30:1045-1052.

Osenberg, C.W. 1989. Resource limitation, competition and the influence of life history in a freshwater snail community. Oecologia 79:512-519.

Peacor, S.D. and E.E. Werner. 2001. The contribution of trait-mediated indirect effects to the net effects of a predator. Proceedings of the National Academy of Sciences 98:3904-3908.

Pointier, J.P. and P. David. 2004. Biological control of Biomphalaria glabrata, the intermediate host of schistosomes, by Marisa cornuarietis in ponds of Guadeloupe: long-term impact on the local snail fauna and aquatic flora. Biological control 29:81-89.

Pointier, J.P., A. Théron, D. Imbert-Establet, D., and G. Borel. 1991. Eradication of a sylvatic focus of Schistosoma mansoni using biological control by competitor snails. Biological control 1:244-247.

Posch, H., A.L. Garr, and E. Reynolds. 2013. The presence of an exotic snail, Pomacea maculata, inhibits growth of juvenile Florida apple snails, Pomacea paludosa. Journal of Molluscan Studies 79:383385.

Putnam, A.B. and P. Peckol. 2018. Asymmetric interference competition between herbivorous gastropods, introduced Littorina littorea and indigenous L. obtusata. Marine Ecology Progress Series 594:135-147.

Raw, J.L., N.A Miranda, and R. Perissinotto. 2013. Chemical cues released by an alien invasive aquatic gastropod drive its invasion success. PLoS One 8: e64071.

Rawlings, T.A., K.A. Hayes, R.H. Cowie, and T.M. Collins. 2007. The identity, distribution, and impacts of non-native apple snails in the continental United States. BMC Evolutionary Biology 7:97. 
Reitz, S.R. and J.T. Trumble. 2002. Competitive displacement among insects and arachnids. Annual Review of Entomology 47:435-465.

Relyea, R.A. 2002. Competitor-induced plasticity in tadpoles: consequences, cues, and connections to predator-induced plasticity. Ecological Monographs 72:523-540.

Riley, L.A., M.F. Dybdahl, and R.O. Hall Jr. 2008. Invasive species impact: asymmetric interactions between invasive and endemic freshwater snails. Journal of the North American Benthological Society 27:509-520.

Rundle, S.D. and C. Brönmark, C. 2001. Inter-and intraspecific trait compensation of defence mechanisms in freshwater snails. Proceedings of the Royal Society of London. Series B: Biological Sciences 268:1463-1468.

Shuford, RBE III, P.V. McCormick, J. Magson. 2005. Habitat related growth of juvenile Florida apple snails (Pomacea paludosa). Florida Scientist 68:11-19.

Smith, C., E.H. Boughton, and S. Pierre. 2015. Pomacea maculata (Island Apple Snail) invasion in seasonal wetlands on Florida ranchland: association with plant-community structure and aquaticpredator abundance. Southeast Naturalist 14:561-576.

Snyder, N.F. and H.A. Snyder. 1969. A comparative study of mollusc predation by limpkins, Everglade kites, and boat-tailed grackles. Living Bird 8:177-223.

Snyder, N.F. and H.A. Snyder. 1971. Defenses of the Florida apple snail Pomacea paludosa. Behaviour 40:175-214.

Sykes, P.W., J.A. Rodgers, and R.E. Bennetts. 1995. Snail Kite (Rostrhamus sociabilis). In: Poole A, Gills, F (eds) The Birds of North America, No. 171, The Academy of Natural Sciences, Philadelphia and the American Ornithologists' Union, Washington, DC.

Thomas, J.D., A.S. Lough, R.W. Lodge. 1975. The chemical ecology of Biomphalaria glabrata (Say), the snail host of Schistosoma mansoni Sambon: the search for factors in media conditioned by snails which inhibit their growth and reproduction. Journal of Applied Ecology 421-436.

Turner, R.L. 1996. Use of stems of emergent plants for oviposition by the Florida apple snail, Pomacea paludosa, and implications for marsh management. Florida Scientist 59:34-49.

Turner, A.M., S.A. Fetterolf, and R.J. Bernot. 1999. Predator identity and consumer behavior: differential effects of fish and crayfish on the habitat use of a freshwater snail. Oecologia 118:242-247.

Turner, A.M., R.R. Turner, and S.R. Ray. 2007. Competition and intraguild egg predation among freshwater snails: re-examining the mechanism of interspecific interactions. Oikos 116:1895-1903.

Wight, B.R., P.C. Darby, I. Fujisaki. 2017. Quantifying edge effects on apple snails (Pomacea paludosa) and their eggs at the junction of two wetland habitat types. Journal of Molluscan Studies 83:351359. 
Figures
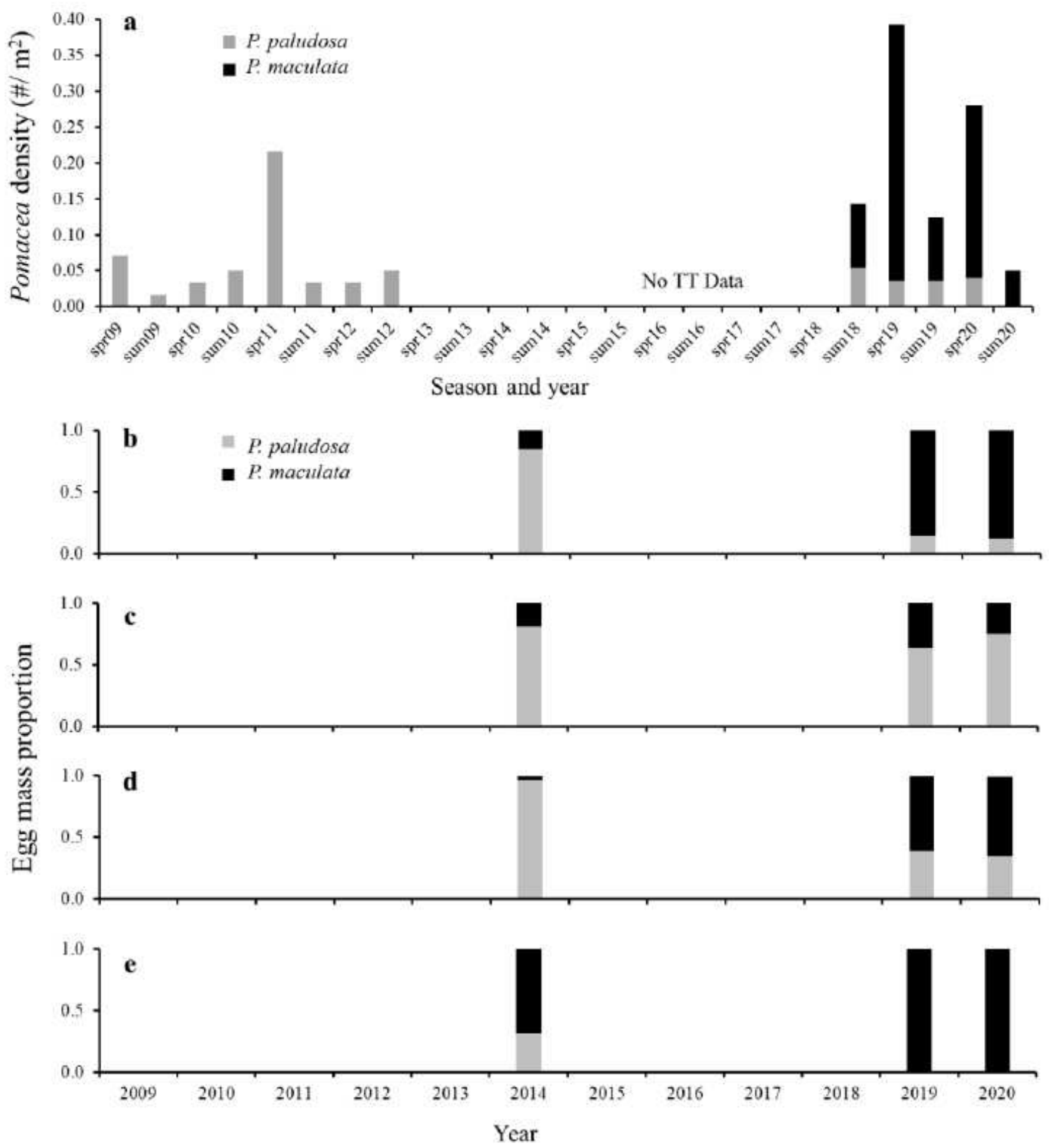

Figure 1

Apple snail species assemblages in LILA wetlands from a average apple snail (Pomacea spp.) densities estimated from throw trap sampling of sloughs (M1-M4) from 2009 to 2020 and b-e composition of observed P. maculata and P. paludosa egg masses on emergent vegetation from $2014(n=1), 2019(n=$ 
7), and $2020(n=9)$ surveys in M1-M4 (b-e). Spring throw trap samples were typically collected in FebMarch and summer samples were collected in July. Means of the species are stacked. In 2009-2012 n = 15 traps wetland-1 were collected (in March 2009 only M3 and M4 were sampled, $n=14$ traps wetland-1) and from 2018-2020 14 traps wetland-1 were collected. No surveying occurred in years without egg mass proportion data
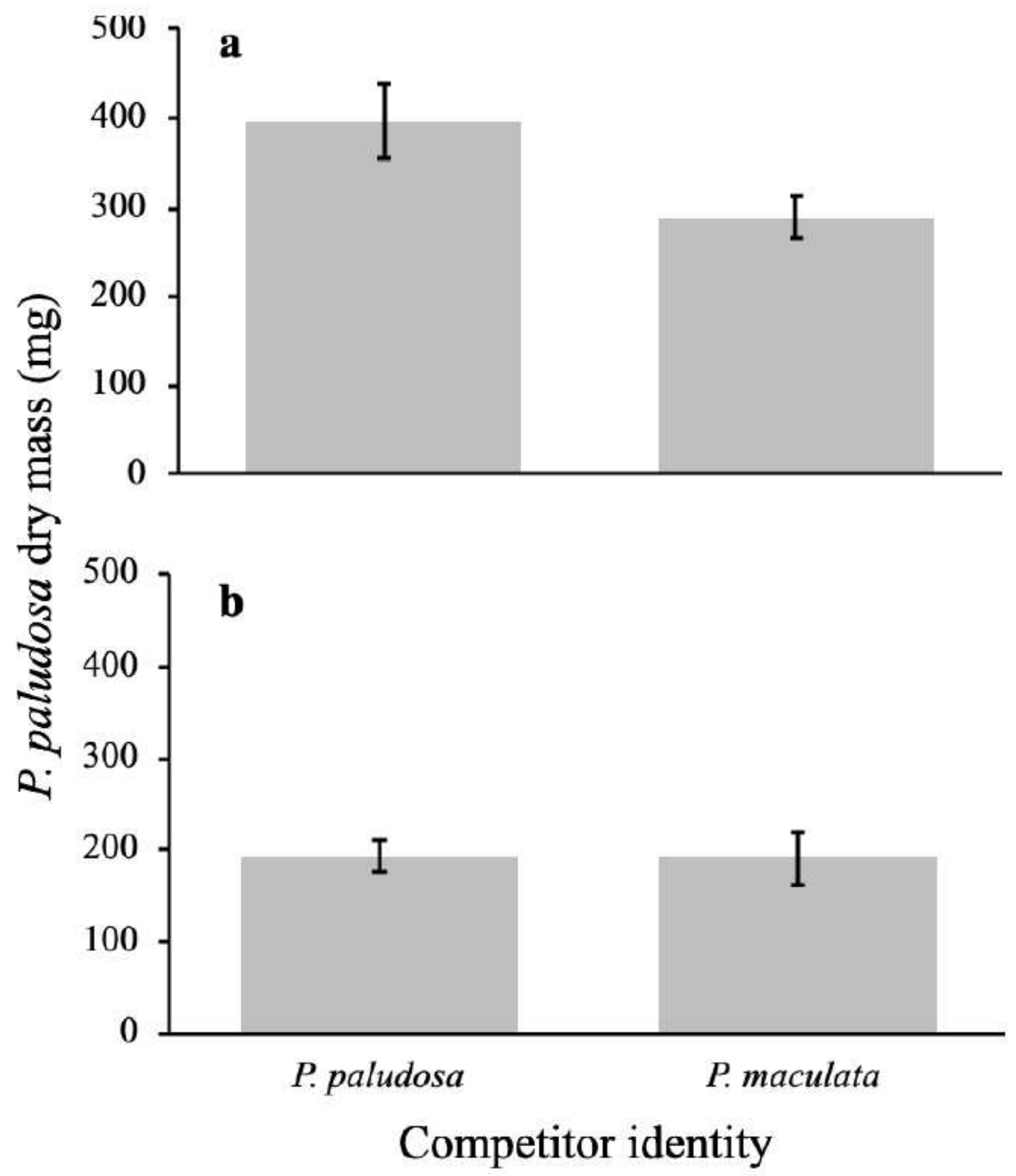

Figure 2 
Mean ( \pm SE) juvenile Pomacea paludosa biomass (mg dry mass) after five weeks growing in experimental field cages placed in wetlands at the Loxahatchee Impoundment Landscape Assessment. Small juvenile snails (3.6-4.4 mg) were stocked into conspecific (only P. paludosa) or heterospecific cages (half P. maculata) using a replacement experimental design. In 2019 a the 1-m2 cages had either 16 P. paludosa or eight P. paludosa plus eight P. maculata ( $n=6$ replicates). In 2020 b experimental cages had either eight P. paludosa or four P. paludosa plus four P. maculata $\cdot m-2(n=10$ replicates)

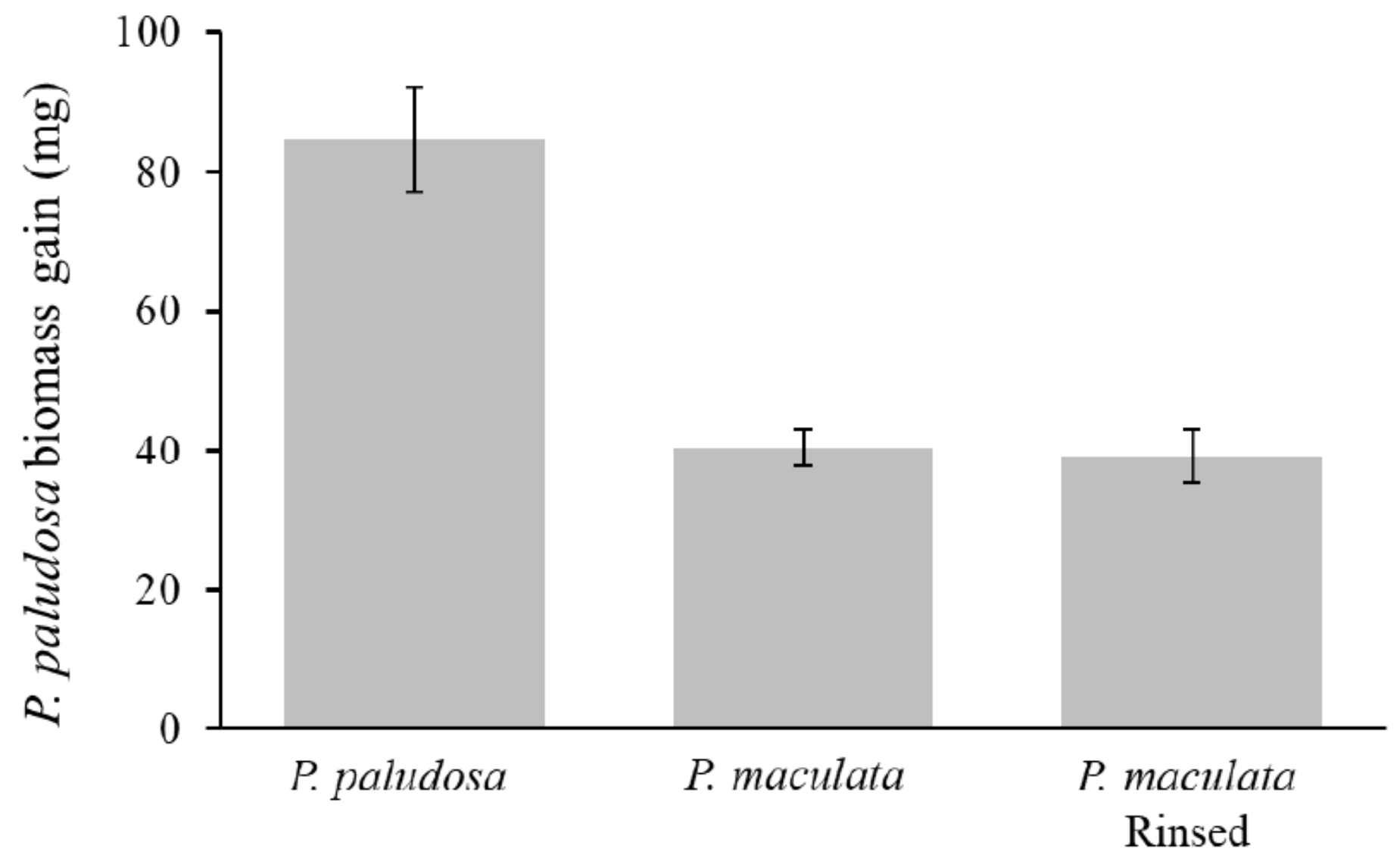

Figure 3

Mean juvenile P. paludosa growth (final - initial mass) after $16 \mathrm{~d}$ growing in chambers with different conditioning treatments. Chambers and food (romaine lettuce) were conditioned with conspecific chemical cues or invasive P. maculata cues. In the third treatment the lettuce was rinsed after conditioning to remove obvious mucus. Chambers were rotated every two days to keep the cues fresh. Each treatment was replicated ten times. Initial snail biomass was $26.2 \pm 1.0 \mathrm{mg}$ (mean $\pm \mathrm{SE}$ ). Error bars represent one standard error 

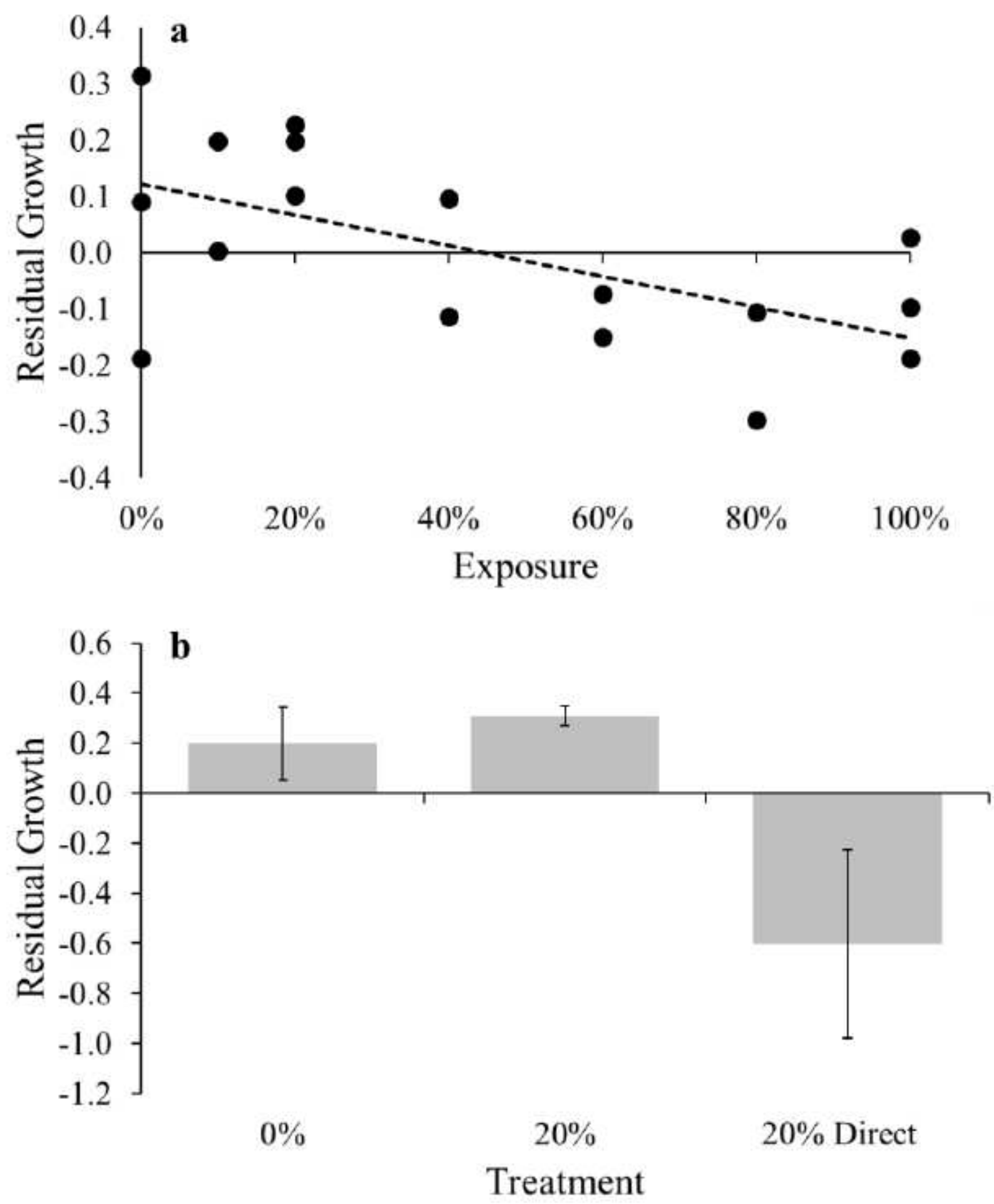

Figure 4

Mean juvenile P. paludosa growth (residual growth) as a function of exposure to adult P. maculata waterborne cues (i.e., amount of time a caged P. maculata was present) (a) or waterborne cues and mucus (20\% direct) (b). Residual growth in each panel represents the mesocosm mean residuals taken from regressions of instantaneous individual growth [In(final mass)-In(initial mass)] against initial mass. Mean residual growth for individual mesocosms are shown in $a$. In panel $b$ the averages of three replicate 
mesocosms ( $n=3$, error bars show standard error) was plotted (no exposure, 20\% waterborne cues only, $20 \%$ waterborne cues plus mucus) 